\title{
Registrácia cirkví a náboženských spoločností $v$ zemiach Vyšehradskej štvorky, Rakúsku a na Ukrajine [Registration of Churches and Religious Societies in the Visegrad Four Countries, Austria, and Ukraine] Ed. Damián NĚmec. Praha 2019, 320 pp.
}

The discussed book is the outcome of the international academic conference held within the framework of the Visegrad Grant No. 21730060. All contributions therein have a unifying theme, namely, the registration of Churches and religious societies in the V4 countries, Austria, and Ukraine, and are written by experts in selected areas of law in the respective countries. The individual text also share internal structure, because their authors always begin with a historical outline of religiosity in a particular country, then proceed to the current legal regulations regarding the individual questions of institutionalised freedom of religion, and finally present unanswered questions and possibilities of their solution de lege ferenda. At the same time, the authors are given the freedom to emphasise the national specifics of individual legal regulations and their articles are obviously accompanied by corresponding bibliographies. The publication in both Slovak and English increases the potential impact of the contributions in question.

The reviewed proceedings combine research on the state of legal regulations with opinions of legal science on the investigated issues. What adds to the quality of the publication is the comparative concluding chapter which summarises and evaluates professional and other approaches to the regulation of marketing authorisations in individual countries, which imply possible sources of inspiration, or deeper reasons for the inability of an individual country to inspire others. 
Let us now discuss individual texts of the book in question:

D. Němec's article on the registration of Churches in Slovakia is well quantified in terms of information; its last chapter directly invites to inspire the results of the research of other authors in the proceedings (in the case of numerical census, although in the Czech Republic, obviously with the necessity to point out important differences between the two countries).

B. Schanda's contribution, in turn, undertakes the topic of Churches registration in Hungary and matches the quality of the remaining texts. The final part of the article lives the readers with an impression that in Hungary Churches do not encounter any major difficulties in terms of registering their activity, but it may result from the neutral tone of Schanda's considerations.

W. Wieshaider's article on regulations in Austria complements other contributions It reflects the specific problems or challenges of the Austrian legislation in multicultural, and so multilingual, environment. Although the Republic of Austria borders the V4 countries, it obviously is not one of them. Of course, it is not to say that the challenges that Austria is facing today will not affect the V4 countries in future, at least to a degree.

M. Sitarz's article on the registration of Churches in Poland also does not point to any conspicuous problems in this regard. However, the data provided by the author concerning the number registered Churches in Poland (166) suggest the need for unification of terminology across analysed group of countries.

Contribution written by K. Bubelová and M. Menke on the registration of Churches in the Czech Republic is a high-quality overview of the situation of Churches and their legal standing in the Czech Republic, especially with regard to how they can operate without registration. In this respect, the situation in the Czech Republic can be a stimulus to address the factual impossibility of registering new Churches in Slovakia.

The article authored by $\mathrm{O}$. Bilash on the registration of Churches in Ukraine is again an inquire the conditions of legal registration of Churches in a state neighbouring the V4 countries. Its value stems from the fact that the legislation in Ukraine often escapes the attention of the public. Moreover, the article by Bilash is absolutely topical, as it maps the major changes made in legislation at the beginning of 2019. As we may learn from the text, these new amendments are already constitute a challenge and prompt some new doubts. 
To summarise, the reviewed book is a valuable and interesting summary of the current legal situation in discussed countries and as such may only be recommended.

Lucia Madleňakova

(D) https://orcid.org/0000-0002-6644-2050 